ISSN (Print):1992-92 18, ISSN (Online):1992-92 18

DOI: https://doi.org/10.32792/utq/utjmed/18/2/5

\title{
Epidemiology Of Ophthalmological Disease In Outpatient Clinic In AL-Nasiriya During 2018
}

\author{
Hala Ali Hussein* (M.B.Ch.B), Prof. \\ Dr. Ali Abd Saadoon** (Ph.D) Community Medicine \\ ali.abd.s@utq.edu.iq \\ Assist.Prof. Dr.Wajida Saad Bunian** (M.Sc.Oph) \\ wajida-s@utq.edu.iq
}

\section{Background:}

Ophthalmological disease especially (ocular allergy) represents one of the most common conditions encountered by ophthalmologists. Some of them are often underdiagnosed and consequently undertreated. Basic and clinical research has provided a better understanding of the cells, mediators, and immunologic events.

Aim: To study the epidemiology profile of ophthalmological disease in Al-Nasiriya at 2018.

Materials and methods: Cross-sectional analytical study involved 1000 patients, attending AlHabboby Teaching hospital_Ophthalmology out patient in Al Nasiriya , the study extended from February to September 2018. Sociodemographic factor ,current history of ophthalmology disease and some determinants, specific investigation had implemented from each patient to assess the frequency ,determinants ,distributions of the commonest ophthalmological disease, (SPSS) version 23 had been in used to analysis data when be p-value $<0.05$ considered as significant statistically.

Results: Female to male ratio was (1.277) Commonest affecting age (35-+2.0), the highest Prevalence ophthalmological disease according prevalence rank as fallow (allergy, viral conjunctivitis, cataract ,bacterial conjunctivitis and foreign body) the result was $(32.1 \%, 14.5 \%, 9.5 \%, 4.6 \%, 4.1 \%)$ respectively. While lowest prevalence of ophthalmological disease was (astigmatism ,hyphema ,lazy eye, hordeolum, sebaceous cyst) the result was $(0.1 \% .0 .1 \%, 0.1 \%, 0.1 \%, 0.1 \%)$ respectively. Where residence and education had significant statistical association.

Conclusion: Allergy are the more commonest ophthalmological diseases in Al-Nasiriya ; Increasing levels of allergy carry significant clinical and economic implications, with more people at risk of the sight-threatening complications associated with high allergy.

Key word: AL Nasiriya ,2018, epidemiology of ophthalmological disease.

*Thi-Qar health directorate

**Thi-Qar university /College of Medicine

Summary 


\section{Introduction:}

The importance of the eye and its function is sometimes underrated, but a consideration of the part played by vision in our consciousness makes as soon as realize its value. If we think of dreams, of memories, of photographs and of almost anything in our daily existence, it is difficult to express them without visual references. ${ }^{[1]}$ After a little careful consideration of the meaning of blindness, it is easy to sense the rational and irrational fears that our patients present to us in the clinic. ${ }^{[2]}$ The personal, social, and economic consequences of blindness and visual impairment continue to be important public health issues, especially in less developed countries. Projected demographic shifts globally suggest that visual loss will continue to be a public health problem into the future. Predictions for the population of the world foretell a "graying of the globe" as the proportion of those aged 65 years and older increases. With this aging will come a shift in the burden of diseases toward the chronic, age-related morbidities seen predominantly now in industrialized countries. This shift will have its parallel in the leading causes of blindness and visual loss, as infectious causes such as trachoma and age-related causes such as cataract increase. ${ }^{[3]}$

Knowledge of the epidemiology will guide both future research and programs targeted toward blindness prevention. Concerted efforts on both fronts are necessary, as the next century holds special significance for the eye care community: The year 2020, beyond the obvious characterization of excellent vision, is the target of the WHO global initiative for the elimination of avoidable blindness control efforts are based, for the most part, on our understanding of the epidemiology of the disease. ${ }^{[4]}$ In this short review, it is impossible to cover epidemiologic research in a field so heterogeneous as diseases of the eye.

Conjunctivitis: pinkeye is redness and inflammation of the thin clear tissue covering the white part of the eye and the inside of the eyelids (conjunctiva). ${ }^{[3]}$

Dry eye: one of the most common diseases of the eye, develops when a reduction in the quantity or quality of tears occurs. ${ }^{[1]}$ A major reason for visits to ophthalmologists. Its prevalence varies widely among epidemiological studies depending on how the disease is defined and diagnosed, and which population is surveyed. It is estimated to be $(7.4 \%-33.7 \%){ }^{[4,5]}$

Allergic conjunctivitis and dry eye syndrome are Two of the most common anterior inflammatory disorders of the eye. These disorders have been regarded to be the epidemics of the 21 stCentury. Both conditions have a strong effect on quality of life. Allergic diseases have dramatically increased in the last decades. ${ }^{[5]}$ The Associated costs have increased substantially as more of the population require treatment for allergies. ${ }^{[3]}$ Ocular allergy can itself produce irritating symptoms and severe forms, such as atopic keratoconjunctivitis, could finally lead to visual loss. ${ }^{[5]}$ Cataract is an opacity of the normally clear lens of the eye. ${ }^{[2]}$ Globally, cataracts cause moderate to severe disability in 53.8 million (2004), 52.2 million of whom are in low and middle income countries. ${ }^{[6]}$ Approximately 3 out of 10,000 children have a cataract. The incidence is variable throughout the world. Cataracts affect nearly 22 million Americans age 40 and 
DOI: https://doi.org/10.32792/utq/utjmed/18/2/5

older. By age 80 , more than half of all Americans have cataracts. Direct medical costs for cataract treatment are estimated at $\$ 6.8$ billion annually. ${ }^{[7]}$ Glaucoma is a condition that causes damage to optic nerve and gets worse over time. ${ }^{[1]}$ As of 2010 , there were 44.7 million people in the world with open angle glaucoma. The same year, there were 2.8 million people in the united states with open angle glaucoma. By 2020, the prevalence is projected to increase to 58.6 million worldwide and 3.4 million the united states. ${ }^{[8]}$ Farsightedness (hyperopia), is a condition of the eye in which light is focused behind, instead of on, the retina. Nearsightedness (myopia), is a condition of the eye where light focuses in front of, instead of on, the retina. ${ }^{[2]}$ The number of people globally with significant refractive errors has been estimated at one to two billion. Rates vary between regions of the world with about $25 \%$ of Europeans and $80 \%$ of Asians affected. The yearly cost of correcting refractive errors is estimated at (3.9 to 7.2) billion dollars in the united states. ${ }^{[9,10]}$ According to the (WHO), there are about(124)million people with refractive errors in the world, 5 million of whom are blind. The prevalence rates of refractive errors have been reported between(1\% and 75\%). ${ }^{[10]}$ Refractive errors can create a heavy financial burden on the society. In addition to the effects of refractive errors on a personal level, reports by the (AAO) indicate that myopia alone has the same adverse effect on The society as headaches and common cold, and that refractive examinations and glasses annually cost patients between $(\$ 1$ to $\$ 1.5$ billion), respectively. ${ }^{[9]}$ Globally, many studies have been performed to identify refractive errors among the elderly, and almost all indicate a high prevalence of refractive errors among them.(8-11) it has been reported that the average age of the population and their life expectancy has considerably increased in the past 40 years, and this has led to an increase in the age ratio of the elderly to the rest of the population. ${ }^{[11]}$ The most effective prevention of eye diseases is good hygiene, healthy diet and Vaccination against Haemophilus Influenza, Pneumococcus, and Neisseria meningitides is also effective. ${ }^{[11,12]}$

\section{Materials and Methods}

The study is observational ,analytical ,cross sectional survey. The period of study started from first week of February- first week September at 2018. The study had been carried out among attendants in outpatient clinic in Al_Habboby hospital in AL-Nasiriya city which is the capital of ThiQar governorate. The study patients includes both sexes (male and female) and all age groups. Sample size it was calculated by the following formula Dobson formula [13]

$$
\text { (1.96)2x p (1-p) x R }
$$

$\mathrm{N}=$ $=1000$

Patients.

$$
\mathrm{d}^{2}
$$

$\mathrm{N}=$ sample size, $\mathrm{P}=$ prevalence rate which is $0.4 \%{ }^{[14]}, \mathrm{d}=$ maximum tolerated error, the value of $0.04, \mathrm{R}=$ Design effect.

The researcher engaged in data collection which counting for three months which involve five day per week 
Web Site: https://jmed.utq.edu.iq

ISSN (Print):1992-92 18, ISSN (Online):1992-92 18

Email:utjmed@utq.edu.iq

DOI: https://doi.org/10.32792/utq/utjmed/18/2/5

- Interview 15 patients minimal and maximal 30 patients per day.

Tools:

Special form of the questionnaire planned to collect information :

Section1:includes questions about identity information (name, age ,sex ,number of family members ,occupation ,marital status, socioeconomic status, education level).

Section2:includes clinical questionnaire( risk factors, health status, family history of ophthalmological disease, recent history ,surgical eye history).

Section3: drug history, exposure. Section 4: on examination tools. Section 5: diagnosis.

Tools: Biomicroscopy slit lamp ,Volk lens ,Air puff tonometer,Visual acuity, Retinoscope, Ophthalmoscope.

The ethical considerations can be specified as one of the most important parts of research, it included the following principles :

- Research participants should not be subjected to harm in any ways.

- Respect for the dignity of research participants should be prioritized.

- Full consent should be obtained from participants prior to the study.

- The protection of the privacy of participants has to be ensured.
- Adequate level of confidentiality of the research data is ensured .

- Any deception or exaggeration about the aim and objectives of the research is avoided.

- Any type of communication in relation to the research are done with honesty and transparency .

- Any type of misleading information, and representation of primary data finding in a biased way are avoided.

\section{Data analysis:}

Statistical Package for Social Sciences (SPSS) version 23 had been used for data analysis. Descriptive statistics expressed in form of , frequencies, percentages, while inferential statistics for testing of associations by test of significance (Chi-square test, or Fisher exact test were used for analysisvariable ), means and standard deviations were used to present data of continuous variables of ophthalmological disease. Correlation and logistic regression analysis were performed to recognize the independent predictors of . A p-value $<0.05$ was considered statistically. 
Thi-Qar Medical Journal (TQMJ):Vol.(18),No.(2),2019

Web Site: https://jmed.utq.edu.iq

ISSN (Print):1992-92 18, ISSN (Online):1992-92 18

Email:utjmed@utq.edu.iq

DOI: https://doi.org/10.32792/utq/utjmed/18/2/5

Results

Total of 1000 patients with Mean age was $(35 \pm 2.0)$ years, The female to male ratio was 1.277 .

Table( 1) : Morbidity profile (prevalence of disease among study patients)

Highest extent represent Allergy( 32.1), Viral conjunctivitis ( 14.5 ), Cataract( 9.5 ) ,Bacterial conjunctivitis ( 4.6 ), Dry eye ( 3.1 ). While the lowest extent Hyphema (0.1 ),Astigmatism ( 0.1$)$, Molluscum(0.2 ), Optic neuritis (0.3)

\section{Table 1: prevalence of disease among study patients}

\begin{tabular}{lll}
\hline & Frequency & Percent \\
\hline Allergy & 321 & 32.1 \\
\hline Foreign Body & 41 & 4.1 \\
\hline Dry Eye & 31 & 3.1 \\
\hline Cataract+ Dry Eye & 5 & .5 \\
\hline Cataract & 95 & 9.5 \\
\hline Glaucoma & 36 & 3.6 \\
\hline Blepheritis & 26 & 2.6 \\
\hline Cellulitis & 3 & .3 \\
\hline Pseudo Dendritic ulcer & 2 & .2 \\
\hline Pterygium & 16 & 1.6 \\
\hline Episcleritis & 2 & .2 \\
\hline Keratoconus & 8 & .8 \\
\hline Viral Conjunctivitis & 145 & 14.5 \\
\hline Naso lacrmal Duct Obs. & 30 & 3.0 \\
\hline Uveitis & 2 & .2 \\
\hline Subconjunctival hage & 11 & 1.1 \\
\hline Periorbital Cellulitis & 1 & .1 \\
\hline Mebomeitis & 6 & .6 \\
\hline Glaucoma+ Pseudo Dendritic Ulcer & 1 & .1 \\
\hline Chalazion & 28 & 2.8 \\
\hline Squint & 13 & 1.3 \\
\hline Retinal Detachment Operation & 2 & .2 \\
\hline Bacterial Conjunctivitis & 46 & 4.6 \\
\hline Hyper sensitivity & 5 & .5 \\
\hline Diplopia & 2 & .2 \\
\hline Maculopathy & 2 & .2 \\
\hline Corneal Burn & 2 & .2 \\
\hline Sebaceous Cyst & 1 & .1 \\
\hline Insect Bite & 6 & .2 \\
\hline Diabetic Retinopathy & 2 & .6 \\
\hline Ophthalmomyiasis & .2 \\
\hline & & \\
\hline
\end{tabular}


Thi-Qar Medical Journal (TQMJ):Vol.(18),No.(2),2019

Web Site: https://jmed.utq.edu.iq

ISSN (Print):1992-92 18, ISSN (Online):1992-92 18

Email:utjmed@utq.edu.iq

DOI: https://doi.org/10.32792/utq/utjmed/18/2/5

\begin{tabular}{|lll}
\hline AMD & 1 & .1 \\
\hline Myopia & 27 & 2.7 \\
\hline Lazy Eye & 1 & .1 \\
\hline Optic Neuritis & 3 & .3 \\
\hline Hordeolum & 1 & .1 \\
\hline Dendritic Corneal Ulcer & 2 & .2 \\
\hline Stye & 2 & .2 \\
\hline Hyphema & 1 & .1 \\
\hline Scleritis & 1 & .1 \\
\hline Macular Hole & 1 & .1 \\
\hline Dermoid & 2 & .2 \\
\hline Hyper metropia & 10 & 1.0 \\
\hline Acute Iritis & 1 & .1 \\
\hline Molluscum & 2 & .2 \\
\hline Astigmatism & 1 & .1 \\
\hline Graves' Disease & 1 & .1 \\
\hline Ischemic Optic atrophy & 1 & .1 \\
\hline Presbyopia & 29 & 2.9 \\
\hline Corneal Abrasion & 10 & 1.0 \\
\hline Trauma & 8 & .8 \\
\hline Vitreous Hemorrhage & 2 & .2 \\
\hline Total & 1000 & 100.0 \\
\hline
\end{tabular}

\section{Diagnosis related to determinants:}

Age: there was significant statistical association between age groups and different eye disorder.

Regarding the allergy, the highest proportion among those who are (45-65) years old $(30.8 \%)$, while the lowest proportion was among those who are more than (65) years old $(4.7 \%)$.

Foreign body disorder showing, the highest proportion among those who are (15-29) years old (41.5\%), while the lowest proportion was among those who are (1-14) years old (7.3\%).

In dry eye disorder, the highest proportion was among those who are (45-65)years old $(35.5 \%)$, and the lowest proportion was among those who are (1-14) and more than (65) years old which were $(9.7 \%)$.

Regarding cataract, the highest proportion was among those who are (45-65) years old (56\%), while the lowest proportion was among those who are (15-29) years old (4\%).

Glaucoma showing, the highest proportion was among those who are (45-65) years old $(50 \%)$, and the lowest proportion was among those who are (1-14) years old (5.6\%).

The infection disorder showing, the highest proportion was among those who are (15-29) years old $(31.1 \%)$, and the lowest proportion was among those who are more than (65) years old $(4.1 \%)$. 
Thi-Qar Medical Journal (TQMJ):Vol.(18),No.(2),2019

Web Site: https://jmed.utq.edu.iq

ISSN (Print):1992-92 18, ISSN (Online):1992-92 18

Email:utjmed@utq.edu.iq

DOI: https://doi.org/10.32792/utq/utjmed/18/2/5

Chalazion showing, the highest proportion was among those who are (15-29) years old (39.3\%), while the lowest proportion were among those who are (45-65) and more than (65) years old, which were $(0 \%)$.

Regarding RE, the highest proportion was among those who are (30-44) years old (32.3\%), and the lowest proportion was among those who are more than (65) years old (1.5\%).

Table( 2):distribution of disease related to age

\begin{tabular}{|c|c|c|c|c|c|c|c|}
\hline \multirow[t]{2}{*}{ DX } & & \multicolumn{5}{|c|}{ recoded age } & \multirow[t]{2}{*}{ Total } \\
\hline & & $1-14$ & $15-29$ & $30-44$ & $45-65$ & $>56$ & \\
\hline \multirow[t]{3}{*}{ Allergy } & No. & 68 & 64 & 75 & 99 & 15 & 321 \\
\hline & Row \% & $21.20 \%$ & $19.90 \%$ & $23.40 \%$ & $30.80 \%$ & $4.70 \%$ & $100.00 \%$ \\
\hline & column $\%$ & $44.20 \%$ & $36.40 \%$ & $41.40 \%$ & $39.90 \%$ & $26.80 \%$ & $39.40 \%$ \\
\hline \multirow{3}{*}{$\begin{array}{l}\text { Foreign } \\
\text { body }\end{array}$} & No. & 3 & 17 & 12 & 8 & 1 & 41 \\
\hline & Row\% & $7.30 \%$ & $41.50 \%$ & $29.30 \%$ & $19.50 \%$ & $2.40 \%$ & $100.00 \%$ \\
\hline & column $\%$ & $1.90 \%$ & $9.70 \%$ & $6.60 \%$ & $3.20 \%$ & $1.80 \%$ & $5.00 \%$ \\
\hline \multirow[t]{3}{*}{ Dry eye } & No. & 3 & 5 & 9 & 11 & 3 & 31 \\
\hline & Row\% & $9.70 \%$ & $16.10 \%$ & $29.00 \%$ & $35.50 \%$ & $9.70 \%$ & $100.00 \%$ \\
\hline & column $\%$ & $1.90 \%$ & $2.80 \%$ & $5.00 \%$ & $4.40 \%$ & $5.40 \%$ & $3.80 \%$ \\
\hline \multirow[t]{3}{*}{ Cataract } & No. & 8 & 4 & 12 & 56 & 20 & 100 \\
\hline & Row\% & $8.00 \%$ & $4.00 \%$ & $12.00 \%$ & $56.00 \%$ & $20.00 \%$ & $100.00 \%$ \\
\hline & column $\%$ & $5.20 \%$ & $2.30 \%$ & $6.60 \%$ & $22.60 \%$ & $35.70 \%$ & $12.30 \%$ \\
\hline \multirow[t]{3}{*}{ Glaucoma } & No. & 2 & 4 & 4 & 18 & 8 & 36 \\
\hline & Row\% & $5.60 \%$ & $11.10 \%$ & $11.10 \%$ & $50.00 \%$ & $22.20 \%$ & $100.00 \%$ \\
\hline & column $\%$ & $1.30 \%$ & $2.30 \%$ & $2.20 \%$ & $7.30 \%$ & $14.30 \%$ & $4.40 \%$ \\
\hline \multirow[t]{3}{*}{ Infection } & No. & 47 & 60 & 41 & 37 & 8 & 193 \\
\hline & Row\% & $24.40 \%$ & $31.10 \%$ & $21.20 \%$ & $19.20 \%$ & $4.10 \%$ & $100.00 \%$ \\
\hline & column $\%$ & $30.50 \%$ & $34.10 \%$ & $22.70 \%$ & $14.90 \%$ & $14.30 \%$ & $23.70 \%$ \\
\hline
\end{tabular}


Thi-Qar Medical Journal (TQMJ):Vol.(18),No.(2),2019

Web Site: https://jmed.utq.edu.iq

ISSN (Print):1992-92 18, ISSN (Online):1992-92 18

Email:utjmed@utq.edu.iq

DOI: https://doi.org/10.32792/utq/utjmed/18/2/5

\begin{tabular}{|c|c|c|c|c|c|c|c|}
\hline \multirow[t]{3}{*}{ Chalazion } & No. & 10 & 11 & 7 & 0 & 0 & 28 \\
\hline & Row\% & $35.70 \%$ & $39.30 \%$ & $25.00 \%$ & $0.00 \%$ & $0.00 \%$ & $100.00 \%$ \\
\hline & column $\%$ & $6.50 \%$ & $6.30 \%$ & $3.90 \%$ & $0.00 \%$ & $0.00 \%$ & $3.40 \%$ \\
\hline \multirow[t]{3}{*}{$\mathrm{RE}$} & No. & 13 & 11 & 21 & 19 & 1 & 65 \\
\hline & Row\% & $20.00 \%$ & $16.90 \%$ & $32.30 \%$ & $29.20 \%$ & $1.50 \%$ & $100.00 \%$ \\
\hline & column $\%$ & $8.40 \%$ & $6.30 \%$ & $11.60 \%$ & $7.70 \%$ & $1.80 \%$ & $8.00 \%$ \\
\hline \multirow[t]{3}{*}{ Total } & No. & 154 & 176 & 181 & 248 & 56 & 815 \\
\hline & Row\% & $18.90 \%$ & $21.60 \%$ & $22.20 \%$ & $30.40 \%$ & $6.90 \%$ & $100.00 \%$ \\
\hline & column $\%$ & $100.00 \%$ & $100.00 \%$ & $100.00 \%$ & $100.00 \%$ & $100.00 \%$ & $100.00 \%$ \\
\hline
\end{tabular}

Figure 1:Relationship between disease and sex

Socioeconomic status: even though there was no significant statistical association, the highest proportion of all eye problem was among those who are located within low social class, and the lowest proportion located with high social class.

Table (3):distribution of disease according to Socioeconomic status.

\begin{tabular}{|c|c|c|c|c|c|c|}
\hline \multirow[b]{2}{*}{ DX } & & \multicolumn{3}{|c|}{ Socioeconomic status } & \multirow[t]{2}{*}{ Total } & \multirow{2}{*}{$\begin{array}{l}\text { X2 } \\
\mathrm{P} \text { value }\end{array}$} \\
\hline & \multirow{3}{*}{ allergy } & Low & Moderate & High & & \\
\hline & & 211 & 93 & 17 & 321 & $11.516^{\mathrm{a}}$ \\
\hline & & $65.7 \%$ & $29.0 \%$ & $5.3 \%$ & \multicolumn{2}{|l|}{$100.0 \%$} \\
\hline & Foreign body & 23 & 18 & 0 & 41 & 0.645 \\
\hline & & $56.1 \%$ & $43.9 \%$ & $0.0 \%$ & \multicolumn{2}{|l|}{$100.0 \%$} \\
\hline & Dry eye & 17 & 13 & 1 & \multicolumn{2}{|l|}{31} \\
\hline & & $54.8 \%$ & $41.9 \%$ & $3.2 \%$ & \multicolumn{2}{|l|}{$100.0 \%$} \\
\hline & Cataract & 56 & 40 & 4 & \multicolumn{2}{|l|}{100} \\
\hline & & $56.0 \%$ & $40.0 \%$ & $4.0 \%$ & \multicolumn{2}{|l|}{$100.0 \%$} \\
\hline & Glaucoma & 23 & 12 & 1 & \multicolumn{2}{|l|}{36} \\
\hline & & $63.9 \%$ & $33.3 \%$ & $2.8 \%$ & \multicolumn{2}{|l|}{$100.0 \%$} \\
\hline & Infection & 121 & 62 & 10 & \multicolumn{2}{|l|}{193} \\
\hline & & $62.7 \%$ & $32.1 \%$ & $5.2 \%$ & \multicolumn{2}{|l|}{$100.0 \%$} \\
\hline & Chalazion & 18 & 9 & 1 & \multicolumn{2}{|l|}{28} \\
\hline & & $64.3 \%$ & $32.1 \%$ & $3.6 \%$ & \multicolumn{2}{|l|}{$100.0 \%$} \\
\hline & $\mathrm{RE}$ & 44 & 17 & 4 & \multicolumn{2}{|l|}{65} \\
\hline & & $67.7 \%$ & $26.2 \%$ & $6.2 \%$ & \multicolumn{2}{|l|}{$100.0 \%$} \\
\hline \multirow[t]{2}{*}{ Total } & No. & 513 & 264 & 38 & \multicolumn{2}{|l|}{815} \\
\hline & Row\% & $62.9 \%$ & $32.4 \%$ & $4.7 \%$ & \multicolumn{2}{|l|}{$100.0 \%$} \\
\hline
\end{tabular}

Figure 2:Relationship between disease and positive history Logistic regression 
Web Site: https://jmed.utq.edu.iq

ISSN (Print):1992-92 18, ISSN (Online):1992-92 18

Email:utjmed@utq.edu.iq

DOI: https://doi.org/10.32792/utq/utjmed/18/2/5

\section{Discussion:}

\section{Strength of study :}

1.Study that in Al Nasiriya city exploring the main and detailed frequency and percentage of predictor problem and its determinant .

2.Involving a large number of study patients.

\section{Limitations of the study:}

- This study is a cross sectional study in which, the temporal relationship cannot be assessed.fallow up main outcome sequiliy of disease, progression of management.

- Variability in definitions and classifications of symptoms and variables between different countries.

- Limitation related to the method used for diagnosis of ophthalmological disease, the question were subjective.

- Missing of seasonal effect because time limit of study.

Study in Khorasan. Prevalence of Refractive Error and its Determinants in Elderly population in Mashhad. The mean age of the participants was (63.7 \pm 7.1 ) years, $(35.4 \%)$ were women and( $64.6 \%$ ) were men .The prevalence of myopia in Khorasan study was (27.2\%) ; $(22.5 \%)$ in women and $(29.6 \%)$ in men .The prevalence of hyperopia was $(51.6 \%)$ was $(31.8 \%)$ in women and $(40.6 \%)$ in men. ${ }^{[15]}$
In recent years, studies have been performed to identify the extent of this issue in Iran. In a comprehensive study known as the "Tehran Eye Study" the prevalence rates of myopia ,hyperopia, and astigmatism were found to be $(21.8 \%, 26.0 \%$, and $29.6 \%)$ respectively. Some studies, including one conducted in Zahedan and one on Dezful school children, have provided valuable information. ${ }^{[16]}$

In the present study (43.9\%) male, while female $(56.1 \%)$. prevalence of myopia( $2.7 \%$ ) , hypermetropia ( $1 \%$ ),presbyopia $(2.9 \%)$. The difference between Khorason, Tehran and present thesis duo to study epidemiology of ophthalmological disease at all not only single diseases and no other similar study.

The majority of age were within (45-65) years old were $(29.5 \%)$, while the minority $(6.1 \%)$ were more than (65) years old, without significance difference between sex groups.

A. Allergy: the highest proportion among those who are(45-65) years old $(30.8 \%)$,while the lowest proportion was among those who are more than (65) years old (4.7\%).In Tikrit prevalence of allergy conjunctivitis was $57 \% .{ }^{[17]}$ In the study the highest incidence of conjunctivitis is seen in the younger age group $52 \%$ of cases are within (0-20) 
Web Site: https://jmed.utq.edu.iq

ISSN (Print):1992-92 18, ISSN (Online):1992-92 18

DOI: https://doi.org/10.32792/utq/utjmed/18/2/5

years. The youngest patient is 4 days old

and the oldest patient is 75 years. ${ }^{[18]}$

The reason of high prevalence in these studies (Tikrit, karantaka) compare with our study due to different in design, our thesis study epidemiology of ophthalmological diseases not only single diseases and no other similar study.

B. Infection : Showing, the highest proportion was among those who are (15-29)years old (31.1\%), and the lowest proportion was among those who are more than (65)years old $(4.1 \%)$.

In our study prevalence of bacterial conjunctivitis (4.6\%),while viral conjunctivitis $(14.5 \%)$ ).This due to viral more contagious than bacterial and increase shedding.

Study in Tikrit city about higher incidence of adenoviral conjunctivitis occurred in about $52 \%$ of cases, because Tikrit city is the center of traditional treatment of eye disease, outbreak of disease .While in our study the prevalence of adenoviral conjunctivitis $(14.5 \%)$ less than in Tikrit .while in bacterial conjunctivitis was $(43 \%)$. ${ }^{[19]}$ Our thesis study epidemiology of ophthalmological diseases not only single diseases.

Residence: Allergy, foreign body, cataract, glaucoma, infection, the highest proportion was among those who are lived in semi urban area, which were (58.6\%, 61\%, 46\%, 41.7\%, 46.1\%) respectively. The lowest proportion was among those who are lived in rural area which were $(4.9 \%, 3.6 \%)$. semi urban cases were more than urban cases probably because medical college hospital has a semi urban feeding population.

Study in Saudi about prevalence of dry eye disease often or constantly is $(32.1 \%)$. Saudi Arabia has a hot desert climate with a temperature reaching more than $\left(50^{\circ} \mathrm{C}\right)$ in the summer months. ${ }^{[58]}$ In this study the same climate in Saudi prevalence of dry eye $(48.4 \%)$ in Urban area .The difference between present study and study in Saudi because our thesis study epidemiology of ophthalmological diseases not only single diseases.

Another study in Babylon about the prevalence of dry eye in the hospital based group ranged from the peak prevalence noted in summer is selfexplanatory. Iraq's summer is usually very severe, with peak temperatures that may reach up to $\left(51 \mathrm{C}^{\circ}\right)$ and nil precipitation and (the shamal) brings extremely dry wind $(14.5 \%-43.6 \%) .{ }^{[20]}$ In present study prevalence is $(3.1 \%)$ of dry eye .The difference between study due to design of study.

Occupation: In the present study show most of them were housewife $(35.7 \%)$. The other proportions of selfemployment, student, employment, child, and retired were approximated (16.4\%, 14.9\%, 13.8\%, 10.6\%, 6.4\%) 
Web Site: https://jmed.utq.edu.iq

ISSN (Print):1992-92 18, ISSN (Online):1992-92 18

Email:utjmed@utq.edu.iq

DOI: https://doi.org/10.32792/utq/utjmed/18/2/5

respectively. The lesser proportion was solider (8\%).

Regarding allergy, foreign body, dry eye cataract, glaucoma. The highest proportion was $(40.8 \%$, $51.2 \%, 54.8 \%, 47 \%$, and $38.9 \%$ ). Study in Iran about prevalence of refractive error among school children(primary and middle school) in rural and urban area were myopic (3.4\%)and (16.6\%) hyperopic. ${ }^{[21]}$

The global prevalence of glaucoma for population aged (40-80)years is $(3.54 \%)$ . The prevalence of POAG is highest in Africa (4.20\%), and the prevalence of PACG is highest in Asia (1.09\%). In 2013, the number of people (aged 40-80 years) with glaucoma worldwide was estimated to be 64.3 million, increasing to 76.0 million in 2020 and 111.8 million in 2040. ${ }^{\text {[21] }}$

Prevalence of present study indicates that lack of awareness regarding glaucoma and poor compliance with medications are the most important barriers to treatment for subjects who are blind due to glaucoma.

Educational level :showing, the highest proportion was primary level, while other proportion of secondary, college and above, lowest proportion. Regarding allergy, foreign body, dry eye cataract

\section{Conclusions :}

1.This study reveals that large number of studied population in our society suffer from allergy conjunctivitis and its and glaucoma. The highest proportion was $(66.7 \%, 68.3 \%, 64.5 \%, 58 \%$ and $58.3 \%$ ) All of them was primary(low education level).

Socioeconomic Status: The highest proportion of all eye disease was among those who are located within low social class, and the lowest proportion located with high social class.

Study In at Ibn Al-Haetham Teaching Eye Hospital (IAHTEH), Baghdad, Iraq, From September 1 To November 30, 2007 the result of study was cataract (76.1\%), diabetic retinopathy (12.9\%), and glaucoma (5\%) were the leading causes of blindness. The majority of blind patients had low socioeconomic status and poor educational level. In cases of cataract, the most important barrier to treatment was the waiting list at the hospital $(53.7 \%)$. The difference duo to sample size ,design of study. ${ }^{[22]}$

Smoking : Even though there was no significant statistical association, the highest proportion was among those who are non-smoker, while there was a comparable result among those who are smoker and ex- smoker. Study in India about smoking and its association with cataract higher prevalence among smoker (1.44\%)compared with nonsmoker. Our thesis prevalence among cataract patient who smoker $(2 \%){ }^{[23]}$

complication, virtually that might have a significant impact on individuals 
Thi-Qar Medical Journal (TQMJ):Vol.(18),No.(2),2019

Web Site: https://jmed.utq.edu.iq

ISSN (Print):1992-92 18, ISSN (Online):1992-92 18

Email:utjmed@utq.edu.iq

DOI: https://doi.org/10.32792/utq/utjmed/18/2/5

themselves, their family and economic

burden.

2.The highest prevalence of allergy conjunctivitis was among age (>45-65 )years old, of male gender, married, of primary level of education, of housewife occupation, of semi urban residence, not have eye surgery.

3.The risk factors which had significant statistical association By univariate analysis were age, sex, marital status, occupation, family member, chronic eye disease, smoking habit, and the total clinical manifestations, this may reflect the high prevalence of risk factors.

4.Multivariate analysis show significant statistical and epidemiological association were with residence, eye surgery, education, family history.

Recommendations:

- Screening health program for (diabetic and hypertensive) patient to investigation and Examination of eyes to detected early complication.

- The family Planning activities to mitigate of ophthalmological disease and complication must be reinforced.

- Reinforce the technique of treatment and provide drugs of eye diseases.

\section{Referance:}

- $\quad$ Bowling, B.,Text book Kanski’s Clinical Ophthalmology Eight. Edition,2016. Chapter 5,page 153.

2. Alloway, N.R.G., Text book Common Eye Diseases and their Management Fourth Edition,chapter 6,page 50, 2016.

3. Singh, K. and L. Bielory, Ocular allergy: a national epidemiologic study. Journal of Allergy and Clinical Immunology, 2007. 119(1): p. S154.

4. Vaughan and Asburys, LANGE text book of Gerenal Ophthalmology, $19^{\text {th }}$ Edition,2018.

5. Singh, K. And L. Bielory. Epidemiology Of Ocular Allergy Symptoms In Regional Parts Of The United States In The Adult Population . In Annals Of Allergy Asthma \& Immunology. 2007. Amer Coll Allergy Asthma Immunology 85 West Algonquin Rd Suite 550, Arlington Hts, Il 60005 USA.

6. Ram,Jagat;Gupt2016 Pataliod Cataract, New England Journal of Medicine vol.374,Issue 18,Pages e22.

7. Robman, L. and H. Taylor, External factors in the development of cataract. Eye, 2005. 19(10): p. 1074.

8. Wang, Y.X., et al., Prevalence of glaucoma in North China: the Beijing eye study. American journal of ophthalmology, 2010. 150(6): p. 917-924.

9. Brien A. Global Prevalence of Myopia and High Myopia and Temporal Trends from 2000 through 2050 Journal of Ophthalmology,Volume 123, Issue 5, Pages 1036-1042.

10. Thomas A. Mavracanas Achilleas Mandalos ;Prevalence of myopia in a sample of Greek students , Vol 78,Issue 6,24 December 2001. 
Thi-Qar Medical Journal (TQMJ):Vol.(18),No.(2),2019

Web Site: https://jmed.utq.edu.iq

ISSN (Print):1992-92 18, ISSN (Online):1992-92 18

Email:utjmed@utq.edu.iq

DOI: https://doi.org/10.32792/utq/utjmed/18/2/5

11. Medically reviewed by University of Illinois-Chicago, College of Medicine on April 5, 2016 - Written by the Healthline Editorial Team.

12. CDC. . Non-Communicable disease unit fact sheet. [Accessed 21 June 2018]. Available from: http://www.cdc.gov/.../non-communicable-diseaseunit-fact.

13. 158. Scribd. 2011. Sampling method, size and calculation. Available from: http://ar.scribd.com/doc. [Accessed 30 July 2018].

14. Bielory, L. and M.H. Friedlaender, Allergic conjunctivitis. Immunology and allergy clinics of North America, 2008. 28(1): p. 43-58.

15. Abbas Ali Yekta,Akbar Fotouhi .Prevalence of Refractive Errors and its Determinants in the Elderly Population of Mashhad, Iran, Volume16,2009 Issue3.

16. Alaa Zanzal Ra'ad Al-Dorri* And Wa'ad Mahmood Ra'uf Al-Jebouri Zanzali Jebouri .Prevalence of allergy conjunctivitis...,Medical Journal Of Tikrit, ISSN: 16831813 Year: 2005.

17. S. Biradar, DK Chandrashekhar, R Gangane... - Int J Pharm Biomed. Spectrum of microbial keratitis and antimicrobial susceptibility at tertiary care teaching hospital Study Carried Out In Medical College Hospital, at 2012.

18. Usama Jihad Abdul Qader. The prevalence of adenoviral conjunctivitis in Tikrit district and the role of traditional medicine "Om Al Kaash" in transmission of the disease and in the severity of complications. Medical Journal Of Tikrit, ISSN: 16831813 Year: 2011.

19. Dr. Abdulaziz Anazi Alshamran Prevalence and Risk Factors of Dry Eye Symptoms in a Saudi Arabian Population ,May And August 2016 In Al-Ahsa Governorate, Eastern Province Of Saudi Arabia; PMCID: PMC5598305 ,PMID: 28936049.

20. A'sad Ja'ffar Alt'ai .Prevalence of dry eye in the hospital based group ranged from the peak prevalence noted in Summer ..., Medical Journal Of Babylon, Year: 2009 Volume: 6 Issue: 2 Pages: 201-206.

21. Yaniv Barkana, Syril Doraiaj Global Prevalence Of Glaucoma And Projection Of Glaucoma Burden Through 2040 ,Vol 122, Issue 7, July 2015 ,Pages E 40-E 41.

22. Faiz I Al-Shakarchi. Blindness in Iraq: Leading causes, target patients, and barriers to treatment. Middle East African Journal of Ophthalmology. At Ibn Al-Haetham Teaching Eye Hospital (Iahteh), Baghdad, Iraq. Vol 18.Issue 3.Page 199-203.

23. Sannapaneni Krishnaiah; Kovai Vilas;Smoking and Its Association with Cataract: Results of the Andhra Pradesh Eye Disease Study from India. Visual Science January 2005, Vol.46, 58-65. 


\section{دراسة معدل انتشار ومحددات أمراض العيون في العيادة الخارجية في

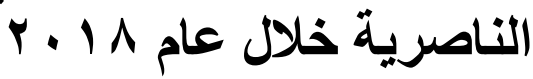

د.علي عبد سعدون

د. هالة علي حسين

دواجده سعد بنيان

الخلاصة

الخلقية: أمر اض طب العيون وخصوصا حساسيه الملتحمة من أكثر الحالات شيوعا التي يوجها أطباء العيون. التهاب الملتحمة غالبا ما يتم تشخيصه وتحديده. البحوث الأساسية والسريرية التهية ، التي التي لايها فهم أفضل للخلايا والوسطاء والاحداث المناعية ، والتي التي تحدث في في حساسية العين. الأهداف: أجريت هذه الدراسة لقياس وبائيات أمراض العيون في العيادات الخارجية في الناصرية $r \cdot 11$

$$
\text { عام }
$$

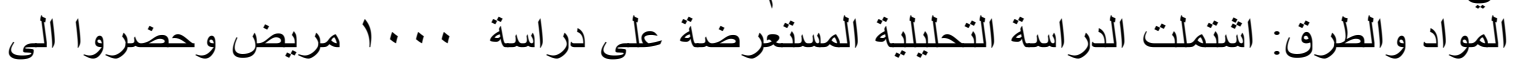

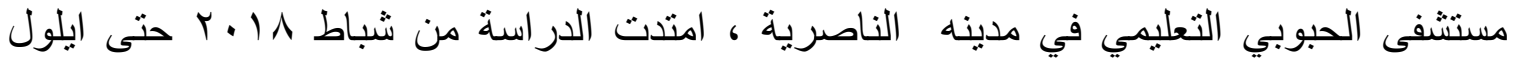

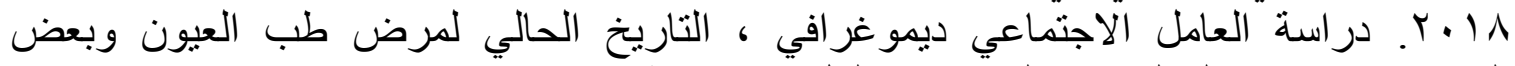

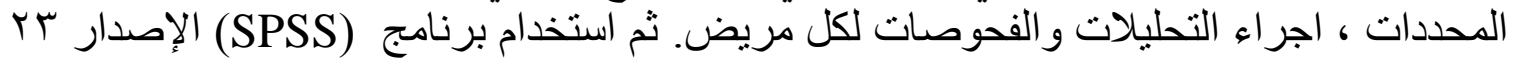

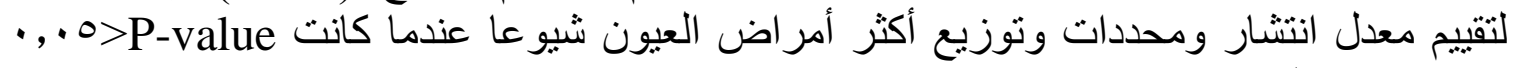
تعتبر ذات دلالة إحصائية.

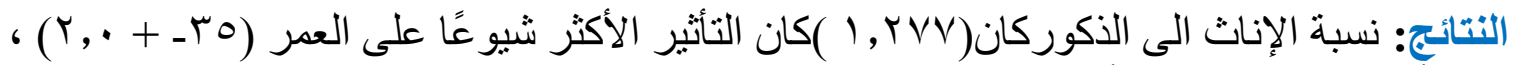

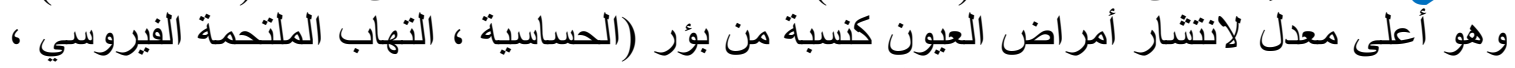

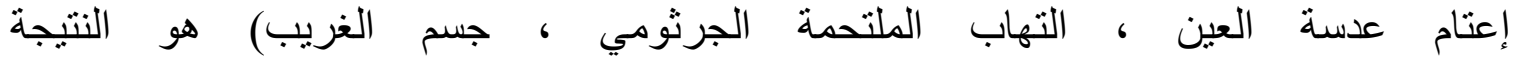

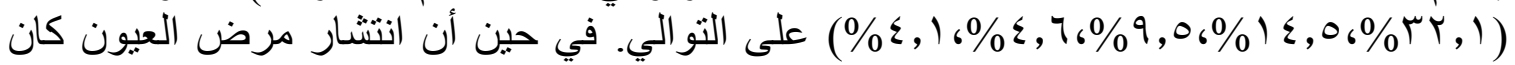

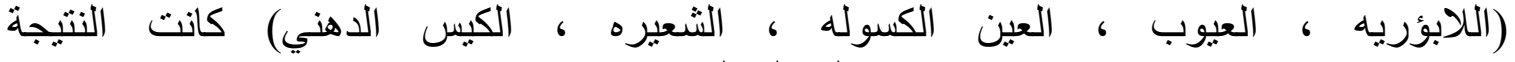

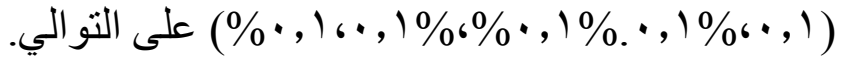

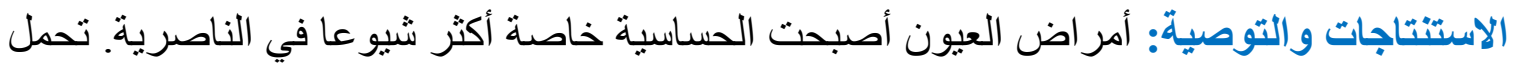
مستويات متز ايدة من الحساسية تأثيرات سريرية واقتصادية كبيرة ، مع تعرض مزيد من من الناس لمضاعفات 